Brit. J. industr. Med., 1953, 10, 173.

\title{
LEGISLATION AND LITIGATION COMMENTS ON THE DEVELOPMENT OF INDUSTRIAL LAW
}

\author{
BY \\ W. MANSFIELD COOPER \\ From the Faculty of Law, the University of Manchester
}

It is usually suggested that the three great sources of our law are case law (in the sense of the "common" law), equity, and legislation, and that, historically, this is the order of their coming; first the common law, then equity, then parliamentary legislation. But, though it contains truth, such a view is too simple. It is too commonly imagined that the common law relates to something in the past which has yielded place, under the strain of modern conditions, to a much more rapid and efficient system of law making by parliament and executive. In fact, on the one hand, the common law is still with us - still creatively with us-and on the other, legislation has had a decisive influence in certain fields for seven hundred to eight hundred years. Indeed, as has been pointed out by Ilbert $(1901)^{1}$ :

"There have been three great constructive periods of English Legislation - the Edwardian period, which laid the foundations of our political and judicial institutions; the Tudor period, which came after the close of feudalism and at the beginning of the new monarchy', which strove to give effect to the ideas of the Renascence and Reformation, which dealt vigorously and unsparingly with the mediaeval church, and undertook the responsibility of discharging, through the secular state, functions which had previously been considered to belong to the domain of the Church ; and, lastly, the period which followed the Reform Act of 1832, and which, in some senses may be said to be continuing to-day."

And yet during these periods the common law was not uncreative either. In fact, from the lawyers' point of view there are two kinds of law, in one of which parliament has made itself preeminent and in the other the hold of the courts has been almost unchallenged. What is remarkable is not perhaps that the judge in his function of law maker should continue, but that his elasticity and adaptability should be so marked.

1. Ilbert, C. (1901). Legislative Methods and Forms, p. 211.
One of the first effects of the industrial revolution was to create a spate of legislation, though much of it was what we should now call local legislation : Acts, which empowered the building of bridges, canals, railways. Institutionally, there was no break in the barrenness which had persisted since the great reforms of the Tudors. ${ }^{2}$ But after 1832 the picture changed.

" Take up a volume ", says Ilbert, " of the eighteenth century Statutes and compare it with a volume of the Victorian period, and you will find yourself in a new world. In the eighteenth century there was no local Government Board, no Board of Education, no Board of Agriculture. . . . Nor were there county councils, district councils, parish councils. The functions of the central and local authorities were comparatively few and simple", and he goes on to add, " The net result of the legislative activity which has characterised ... the period since 1832 , has been the building up piecemeal of an administrative machine of great complexity, which stands in as constant need of repair, renewal, reconstruction and adaptation to new requirements as the plant of a modern factory. The legislation required for this purpose is enough, and more than enough, to absorb the whole legislative time of the House of Commons, and the problem of finding the requisite time for this class of legislation increases in difficulty every year." 3

Indeed Parliament in this third period of legislation has come full circle and we are in substance back to the practice of Parliament in the time of the first Edwards, in which the King by his ministers made the law. Parliament's absorption in activity of this kind was a matter of anxiety to common lawyers even before the turn of the century. Writing in 1895 Pollock thought that " the besetting danger of modern law is the tendency of complex fact and minute legislation to leave no room for natural growth, and to choke out the life of principles under a weight of dead matter which posterity might think no better than a rubbish heap." ${ }_{4}$

\footnotetext{
2. Ibid.

3. Ilbert. op. cit., pp. $211,212,213$.

4. Pollock, F. (1904). Expansion of the Common Lan, p. 8.
} Stevens, London. 
Time has shown that this is too conservative a view both of the worth of much parliamentary legislation and of the growth of what has so often been called "lawyers' law", the type of law, which speaking generally, arises from the activities of a judge applied to problems raised by litigation. For Parliament is still relatively little concerned with the rules of contract, tort, property, family relations, succession and inheritance, and the like. And within these fields the anvil of litigation is still extremely potent. Speaking generally, legislation is more usually a mirror of the evils of a society, of the defects from which it suffers, than the pattern of a new society, and the value of Parliament's activities is not so much in the field of creative law as in administrative regulation. From the historical point of view legislation is rather like the written Utopia, not necessarily a valuable guide to the future but a manifestation of the society which gave it birth. Somebody looking at the Bankruptcy Acts in series once remarked that they revealed the problem before Parliament as that of drawing a net narrow enough to catch the rogue but wide enough to let the unfortunate escape. The Factory Acts reveal the same process.

The first of these early efforts at factory legislation was hesitating and tentative in the extreme, even the name, "An Act for the Health and Morals of Apprentices and Others" indicating Parliament's reluctance to wander into the new fields. The Act was aimed at the old parish apprentice system and contained some humane features but was largely ineffective, for it was aimed at a system which had passed its zenith. The habit of employing parish children was yielding to the employment of "free children", whose own parents often were a vested interest against reform, or about whom, since they were employed under a so-called voluntary contract, it was not nearly so easy to rouse public opinion. Other Acts were passed between then and 1833, Acts containing important principles but breaking down almost always on the question of enforcement. It was indeed not until an adequate system of factory inspection was provided that parliamentary legislation became in any way influential, for it was through the inspectors that knowledge became available; through them that the fund of experience upon which legislators might draw became almost inexhaustible, their records and reports yielding a rich dividend in formulating the problems which Parliament must face. Parliament thus began to replace the general obligation by obligations laid down with some care, and the process went so far that between 1901 and 1937 Acts were chiefly aimed at filling gaps or meeting changes imposed by technical or scientific advance. Then in 1937 came an Act which though it has novel provisions is primarily aimed at consolidating the existing law, at excising anomalies, and eliminating obsolete distinctions.

Thus over a century and a quarter Parliament has built up a comprehensive code of minimal requirements in the fields of health, safety, and welfare. But despite all this parliamentary labour there were fearful gaps, and black indeed would have been the plight of the injured worker if the courts had not, by means of adjudications upon cases before them, built supplementary codes of obligation in his favour. For though the Factory Acts showed great concern for the conditions under which a man worked they showed little for the man who was harmed by his employer's failure to obey the law. The employer might be fined for his breach of duty, but the injured workman came under parliamentary consideration at one point only, namely, in the provision that where a workman is killed or injured because of a breach of the Act, the occupier will, without prejudice to any other penalty, be liable to a fine not exceeding $£ 100$ which may be applied in whole or part for the benefit of the injured person or his family. ${ }^{5}$ And the poverty of this remedy is the more striking when it is recalled that almost a century elapsed between the passing of the first Factory Act (1802) and the first Workmens Compensation Act (1897).

Now, by any standards, such provision for loss of life or injury is quite inadequate, and the courts recognized this. An action for negligence would lie, but that too, from the point of view of an injured workman was largely a delusory remedy, for when industry assumed a hierarchical structure to fasten personal negligence on an employer was extremely difficult; to fasten it on anyone less than an employer, meaningless. The courts moved along two lines. In 1854 one Couch, a seaman, suffered illness through the absence on board ship of medicines which the shipowner was required by Statute to provide. It was held that he might recover, although the Act in question, like the later factory acts, merely provided a penalty payable to the State and did not expressly give a right of civil action. ${ }^{6}$ The court, faced with an Act of Parliament passed for the benefit of a particular class of people, containing a penalty but no right of action, will ask itself whether this penalty is intended to be exhaustive : will ask whether it was Parliament's intention to exclude an action upon the part of a person injured by the breach. Thus

5. Factories Act 1937. Sec. 133.

6. Couch v. Steel (1654). Ellis and Blackburn, vol. 3, p. 402. 
the court, on the basis of litigation brought by aggrieved persons, has evolved a civil action for a breach of statutory duty which has been applied to a wide range of Acts, notably to the Factories, the Mines, and the Shops Acts, and thus the courts have done for the injured workmen what Parliament originally did not seem to think it was its duty to do. Today, one cannot take up a volume of law reports without reading cases in which the courts have come to the aid of the injured workman and his family. The civil action for breach of statute has become a part of the legal background of the nation.

The second development was, in its origin, even more interesting, because it is not clear that the judge concerned really foresaw the consequences which were later to arise from certain of his words in the judgment he gave. In 1837 Lord Abinger decided the case of Priestley v. Fowler, ${ }^{7}$ the first case in English law, as far as one can see, in which an injured workman had the temerity to sue his employer. Priestley was employed by a butcher, and in the course of his employment, had to ride on the butcher's cart. This was overloaded, a wheel gave way, and Priestley was injured. Priestley did not allege in the averment that his master knew of any defect in the vehicle, or that it was overloaded, but in evidence made it clear that the master did know this. It was held that the employer was not liable. His Lordship was clearly disturbed, and lest personal comments be deemed biased, let Lord Atkin, discussing the case a century later, be quoted :

"Lord Abinger felt that he had to decide the case on general principles, and was at liberty to look at the consequences one way or the other. Surveying them he was alarmed, for he found that if the master was liable, he would be liable for the negligence of all his 'inferior agents', e.g. to the footman for the negligence of his coachman ; . . . to a domestic servant for the negligence of a chambermaid, the upholsterer, the cook, the butcher and the builder. A more remarkable medley of so called agents it is difficult to conceive. Faced with the absurdity of these consequences, the court concluded that the master is not bound to take more care of the servant than he may reasonably be expected to do for himself " 8 .

Lord Wright went further when he said that " these instances seem to show personal apprehensions rather than any principle"

Historically, the importance of Priestley v. Fowler was twofold. It originated the doctrine of " common employment", an unhappy doctrine which laid

7. Meeson and Welsby, vol. 3, p. 1 .

8. Quotation from the judgment of Lord Atkin in the case of Radcliffe and Ribble Motor Services Ltd. (1939). Appeal Cases vol. 215 , p. 225 .

9. Ibid. at p. 239. down that where a servant was injured as the consequence of the act of another servant upon whose safety he was dependent, this was to be accounted one of the risks of the employment for which the employer would not be responsible. It was a doctrine against which the courts learned to protest and which they refined and distinguished with as much ingenuity as they were capable of, but by which in essence they felt bound. Yet, apart from a limited effort in 1880, it was not until 1948 that Parliament felt sufficiently moved to end the sorry business.

But Priestley v. Fowler had another series of consequences which have been less commented upon than the doctrine of common employment, for the judgment contains what was at that time the novel suggestion that the master owed a duty, as yet vague and undefined, to take reasonable care of the safety of his servant.

"In truth ", Lord Abinger said, " the mere relation of master and servant can never imply an obligation on the part of the master to take more care of the servant than he may reasonably be expected to do for himself. $\mathrm{He}$ is, no doubt, bound to provide for the safety of his servant in the course of his employment, to the best of his judgement, information and belief."

Those words are, in fact, the origin of a code of rights and liabilities which have filled the legislative gaps to which reference has been made. A workman, it is said, must accept the hazards of working alongside his fellow workmen, but this is soon glossed by the courts and it is held that an employer will be liable to his workman for hazards arising from $(a)$ his failure to select servants of competent care and skill, and $(b)$ his failure to safeguard his servant from " unreasonable risks".

The law begins to develop with some rapidity, in Scotland more so than in England, and it comes to be established that a master owes a personal duty of care towards his servant, and that this duty operates in respect of the place of work, the plant, and the machinery involved, and where the master delegates these duties to another, he will none the less remain responsible to that other. The story of these developments is fascinating in the extreme, but cannot be discussed here. It is sufficient to recall that faced with a situation in which the hazards of employment were increasing with great rapidity and with a Parliament which remained, on the whole, mute as to the rights of the individual workman, the courts built up a threefold obligation for the employer ; namely, the obligation to provide a competent staff; the obligation to provide adequate equipment and material ; and the obligation to fuse the two into what the law calls "a 
safe system of working", the latter proving a remarkably elastic and resilient concept by which the courts could secure justice for the injured workman. How can it be contended in the face of this that the courts have ceased to function except in the lesser role of interpreting legislation ? How can it be suggested that the only potent source of law is Parliament? For of course in suggesting that the courts still act in the role of creative law making, I am suggesting what many would regard as heresy.

Yet it is probable that we are to-day witnessing in the same field of litigation a new development which is likely to be as fruitful as was the development of employers' liability last century. The courts are today evolving, it may be suggested, a code of employees' liability of the utmost significance. For in one respect the law, whether the creature of Parliament or of the courts, was defective. A workman who was himself negligent and was injured might find that he could not succeed or could succeed only partially in recovering damages. Indeed it was not until $1940^{10}$ that the House of Lords finally decided that contributory negligence was a defence to an action for breach of statutory duty, and even then it was clear that the courts, in construing what amounted to contributory negligence, would lean in favour of the workman. A workman, it is true, would not recover if he did not take ordinary care for his own safety but the degree of care would vary with the circumstances, and a different degree of care might be expected from a workman in a factory than that which might be expected from an ordinary man not exposed to the noise, strain, and manifold risks of factory or mine. Lord Wright went further. The courts, he said, have accepted contributory negligence as a defence "but the policy of statutory protection will be nullified if a workman were held debarred from recovering because he was guilty of some carelessness or inattention to his own safety ".11 He made it clear that if he had been free to do so, he would have made a workman liable only where his conduct was so grave and so directly caused the accident as to shift responsibility from his employer to himself.

The courts were clearly uneasy, at this stage, about the law ; they were doubtless worried about the disparity of the sanction and the act of carelessness (the sanction being the refusal of civil remedy); they were unwilling to feel that contributory negligence should be a complete defence but felt

10. Caswell v. Powell Duffryn, Associated Collieries Ltd. (1940), Appeal Cases, p. 152

11. Ibid. at p. 179. themselves powerless. Statute came to their aid in 1945 and while the defence of contributory negligence is still available, under the Law Reform (Contributory Negligence) Act 1945, damages are apportionable between the parties according to their degree of culpability.

All this has enabled the courts, secure in the knowledge that the merely careless or stupid workman and his family are not entirely bereft of compensation, to look at the situation which arises when the employer is compelled by Statute to provide safety devices and facilities which the workman fails to use. In the 1937 Factories Act, Section 119, it is provided that a workman must not wilfully do anything likely to endanger himself and others, nor wilfully interfere with or misuse anything provided under the Act for securing health, welfare, and safety and must use any such means or appliances provided. The provision is not strong; it is difficult to see how it could be enforced, except negatively, either by fining the offending workman for his breach of the Act and reducing or denying damages to him if he injured himself. But what of the situation where his action injures his fellows or damages his employer's property? In principle there is no reason why he should not be sued civilly, but there is little to be gained in suing a man of straw. So again, the employer would have to bear the brunt.

But there is some evidence that the courts are looking at these questions anew and are slowly building a code of employees' liability. The statutory provision was first looked at in Wraith \& Flexile Metal Co. Ltd. ${ }^{12}$ A girl worker, in an effort to retrieve a cylinder which had fallen, had crawled under a drying oven and been injured. She sued her employers, who pleaded contributory negligence and her failure to use a safety device provided. For they had given instructions that employees were not to go under the ovens and had provided a broom with which to retrieve any fallen objects. This argument the courts would not accept : the accident, the court believed, arose from a failure securely to fence, and the object of the Factories Act was declared to be the protection of workers against their own folly. At this stage then, it was clear that an employer who was himself in breach could not set up the breach of his employee and might not excuse the absence of a superior safety device by showing that he had employed an inferior one. That was in 1943, but by 1952 it is possible to detect a stiffening in the attitude of the courts. In Norris v. Syndi Manufacturing

12. (1943). King's Bench Division, p. 24. 
Co. Ltd., ${ }^{13}$ a tool setter, while making adjustments, removed from a power press the guard which had been fitted by the defendants and failed to replace it when testing the press in motion. It was held that he could not recover. The defendants in fitting a guard had provided a device for the plaintiff's safety which he was under an absolute statutory duty to use. He was therefore in breach of Section 119 of the Factories Act and damages awarded to him by the trial court must be reduced by one-fifth. There was some evidence that his employers had acquiesced in his working without a guard but this did not unmake the man's own offence. He had a duty independent of the employers for a breach of which he must be responsible in damages.

Two other cases merit discussion. I choose them only because they show developments in principle. The first is of considerable interest, for in Paris v. Stepney Borough Council ${ }^{14}$ the plaintiff, a garage hand who had already lost the sight of one eye, was blinded by a piece of meial which flew when he was attempting to knock a nut from a bolt. Mr. Justice Lynskey in the court of first instance held that the employers were negligent, but the Court of Appeal disagreed. The House of Lords found for the plaintiff, reinstating Mr. Justice Lynskey's decision, though varying the reasons. Mr. Justice Lynskey had said that since the employers were aware of the man's partial blindness, they should have provided goggles. The Court of Appeal, and particularly Lord Justice Asquith, felt that a distinction should be made between risks and consequences. The risks of accident to a partially blind man were not necessarily greater than those to a sighted man, though the consequences of accident were greater, and it was unfair to visit upon the employer those additional consequences. Certainly were it not for the Disabled Persons Act employers, after Paris's case, would have been reluctant to employ disabled persons, for they were increasing their own obligations when they did so.

In Paris's case the employer knew of the defect. What would be the position where the employer had no such knowledge? We had not long to await the answer. Last year the courts heard the case of a workman who was injured by falling from a platform twenty feet above ground level, which, contrary to the building regulations, was not 34 inches wide and did not contain the proper guard and toe rails. But the workman suffered from epilepsy and had been told by his doctors not to work above ground level. It was held that responsibility was equal, and the damages reducable

13. (1952). All England Law Reports, vol. I, p. 935. 14. (1951). Appeal Cases, p. 367. by one half. ${ }^{15}$ The case is extremely important. The seller of goods and services has never been required by the common law to enumerate their defects. Who amongst us would have got a job otherwise ? The duty of disclosure has not existed. It does now, and a new obligation is firmly placed on the shoulders of the workman. In other words, whereas formerly the tendency of the courts was to emphasize the responsibility of the employer, there is now some evidence of a changed emphasis, and the obligations of the workman are the subject of much consideration.

Why, then, have the courts been so effective in a period of much legislative activity, first in developing the law and secondly in the creation of remedies?

Firstly, it may be argued, because of the changed legislative background. Law makers, whether parliamentary or judicial, cannot move far ahead of the zeitgeist, the notion of public policy, of national expediency, of the sovereign people, or what you will. As Mr. Justice Holmes said in Southern Pacific Co. v. Jensen, ${ }^{16}$ " The Common Law is not a brooding omnipresence in the sky, but the articulate voice of some sovereign or quasi sovereign". And the last dozen years have seen important legislative changes: the abolition of the doctrine of common employment, the Law Reform (Contributory Negligence) Act 1945, the creation of a comprehensive system of insurance, domestic and industrial, and the abolition of the system by which the injured workman was put to his election between workmen's compensation and actions at common law. ${ }^{17}$ The first two of these changes - though made by Parliament-owed much to the criticism of the courts. But there has been a century of legislative change in a deeper sense.

"In substance", wrote Oliver Wendell Holmes, " the growth of the law is legislative. And this in a deeper sense than that what the courts declare to have always been the law is in fact new. It is legislative in its ground. The very considerations which judges most rarely mention, and always with an apology, are the secret root from which the law draws all the juices of life. I mean, of course, considerations of what is expedient for the community concerned. Every important principle which is developed by litigation is in fact, and at bottom, the result of more or less definitely understood views of public policy." 1 .

15. Cork v. Kirby Maclean Ltd. (1952). All England Law Reports, vol. 2 , p. 402.

16. Oliver Wendell Holmes (1881). The Common Law, p. 35.

17. The problem of alternative remedies has been shelved, not solved. Because the employer is a contributor to the National Insurance Scheme, The Law Reform (Personal Injuries) Act, 1948. Sec. 2 (1) provides that in certain cases damages at common law are to be reduced by one half the estimated value of the insurance
benefits to be received by the workman.

18. The Common Law (1881), p. 35. Little, Brown, \& C.. Boston. 
In Holmes' sense also, then, there have been legislative changes, though it is not easy to reconcile their consequences. It may have been expedient originally that employers should be protected; that gradually it should be the employee who became the centre of interest. But how to explain a stiffening of the courts' attitude against the workman contemporaneously with the establishment of the welfare state? May it not be that the welfare state will be able to deal more effectively with the workman who fails to use the facilities provided than was possible in a capitalist society? There are indications that it may be so.

Secondly, looking at the last century of law making, admittedly in only one, though as I believe, representative field, one cannot escape the feeling that the machinery of the courts has certain advantages over Parliament where individual rights are concerned, which is perhaps to do nothing more than call attention to the old distinction that laws are general and cases particular. Parliamentary conservatism and inertia are fearsome things and legal inertia and conservatism not less so, but the history of the last century does suggest that it is still possible for men of courage and originality to influence affairs with great effect from the bench. For this also must be said; whatever may be true of its origins, the survival of the common law as a law-making instrument depends as much on a wise departure from accepted tradition as upon insistence upon it. Its development, and hence its usefulness, derive not so much from a bench of judges swearing fealty to the common law and resisting any departure therefrom, as upon one or two judges, progressively minded, thinking always of the ends law must serve and how best it may serve them in our time. One judge of this temper of mind has recently reminded us of this. He was dealing with counsel who had told him that he could not do this and that because there was a lack of authority on the matter.

"The argument about the novelty of the action does not appeal to me. It has been put forward in all the great cases which have been milestones of progress in our law, and it has always, or nearly always, been rejected. If you read the great cases of Ashby v. White, Pasley v. Freeman, and Donoghue v. Stevenson, you will find that in each of them the judges were divided in opinion. On the one side there were the timorous souls who were fearful of allowing a new cause of action. On the other side there were the bold spirits who were ready to allow it if justice so required. It was fortunate for the Common Law that the progressive view prevailed. Whenever this argument of novelty is put forward, I call to mind the emphatic answer given by Pratt, C. J., nearly two hundred years ago in Chapman v. Pickersgill, when he said: "I never wish to hear this objection again ; this action is for a tort : torts are infinitely various, not limited or confined, for there is nothing in nature but may not be an instrument of mischief.' The same answer was given by Lord MacMillan in Donoghue v. Stevenson, when he said : "The criterion of judgment must adjust and adapt itself to the changing circumstances of life. The categories of negligence are never closed.' It needs only a little imagination to see how much the Common Law would have suffered if those decisions had gone the other way." 19

And thirdly, this review does suggest that it is in the development of new causes of action and in the adaptation of old causes to new situations that the courts have had a considerable success. Parliament has built up codes of rights and obligations, so too have the courts, but in this they have followed the traditional common law method of concentrating on remedies. That apparent illogicality-where there is a remedy there is a righthas been a continuing source of strength to the common law. It is so often meaningless to talk of rights if there is not the means to enforce them. The courts throughout the first century of industrial legislation have in fact been not less progressive than Parliament in matters concerning the welfare of the injured workman, and in the creation and enforcement of remedies.

19. From the judgment of Lord Justice Denning in the case of Candler v. Crane, Christmas \& Co. (1951). King's Bench Division, vol. 2 , p. 178 . 